\title{
Establishing the twig method for investigations on pollen characteristics of allergenic tree species
}

\author{
Stephan Jung ${ }^{1}$ (D) $\cdot$ Feng Zhao $^{2} \cdot$ Annette Menzel $^{1,3}$ \\ Received: 28 October 2020 / Revised: 7 May 2021 / Accepted: 19 May 2021 / Published online: 27 May 2021 \\ (C) The Author(s) 2021
}

\begin{abstract}
The twig method in climate chambers has been shown to successfully work as a proxy for outdoor manipulations in various experimental setups. This study was conducted to further establish this method for the investigation of allergenic pollen from tree species (hazel, alder, and birch). Direct comparison under outdoor conditions revealed that the cut twigs compared to donor trees were similar in the timing of flowering and the amount of pollen produced. Cut twigs were able to flower in climate chambers and produced a sufficient amount of pollen for subsequent laboratory analysis. The addition of different plant or tissue fertilizers in the irrigation of the twigs did not have any influence; rather, the regular exchange of water and the usage of fungicide were sufficient for reaching the stage of flowering. In the experimental setup, the twigs were cut in different intervals before the actual flowering and were put under warming conditions in the climate chamber. An impact of warming on the timing of flowering/ pollen characteristics could be seen for the investigated species. Therefore, the twig method is well applicable for experimental settings in pollen research simulating, e.g., accelerated warming under climate change.
\end{abstract}

Keywords Pollen · Allergy $\cdot$ Climate change $\cdot$ Twig experiment

\section{Introduction}

Under climate change, the relevance of aeroallergens including allergenic pollen is expected to increase (Beggs 2004). Nowadays, pollen-related allergic rhinitis already prevails in up to $40 \%$ of the population in Europe (D'Amato et al. 2007). New techniques for the investigation of allergenic pollen are steadily being developed (Sofiev and Bergmann 2013).

The goal of these studies was among others to identify key influences on seasonal patterns and pollen emission, including the effects of climate change (Marselle et al. 2019), and to study pollen characteristics, such as variation in allergic content among different grass species (Jung et al. 2018). It is

Stephan Jung

sjung@wzw.tum.de

1 TUM School of Life Sciences, Department of Life Science Systems, Technical University of Munich, 85354 Freising, Germany

2 Helmholtz Zentrum München - Deutsches Forschungszentrum für Gesundheit und Umwelt $(\mathrm{GmbH})$, 85764 Oberschleißheim, Germany

3 Institute of Advanced Study, Technical University of Munich, 85748 Garching, Germany already known that climate change alters seasonal patterns of pollen, e.g., leading to an earlier start of pollen season (Frei and Gassner 2008; Menzel et al. 2006; Menzel et al. 2020a, b; Rosenzweig et al. 2008). Seasonal patterns and their trends are normally captured by phenological studies and/or longer time series of measured airborne pollen concentrations (e.g., Menzel et al. 2021). In general, pollen characteristics, such as protein content, and allergenicity are obtained from airborne samples using high-volume impactors (Buters et al. 2010; Grewling et al. 2020) or low-volume devices such as multi-vial cyclone samplers (Brennan et al. 2019). However, the acquisition costs for such devices are high and even then, it cannot be ruled out that pollen from more than one individual is collected. Therefore, the study of pollen characteristics of individual species such as birch or hazel usually requires in situ collection of pollen, which should ideally be combined with manipulative experiments on climate change. For the subsequent laboratory analysis, well-established standard methods such as ELISA and Western blot for the determination of allergenic content are used (Bufe et al. 1996; Jung et al. 2018; Schäppi et al. 1999). The necessary in situ collection of pollen is often associated with difficulties, as the pollen has to be stored under suitable conditions immediately after emission. Therefore, pollen collection requires, e.g., air- 
permeable bags that collect the pollen while protecting it from rain and insects and at the same time likely formation of condensed water has to be prevented. Glassine bags which are commonly used in plant crossing attempts offer air permeability but do not fulfill the other requirements (Hanna 1990; Jung et al. 2018).

Here, the twig method in climate chambers may also meet these requirements for in situ pollen collection allowing at the same time variations in environmental conditions. Thus, this method has the benefit that in the face of climate change different climatic scenarios and their impacts on pollen characteristics can be studied. The twig method has already been well described in previous studies (Basler and Körner 2012; Dantec et al. 2014; Menzel et al. 2020a, b; Primack et al. 2015). Vitasse and Basler (2014) observed for the tree species hornbeam, European beech, and sycamore that the timing of budburst is comparable between cut and uncut twigs from a donor tree. Among others, the twig method can be applied for various phenological observations, e.g., to test the influence of winterly (chilling) temperatures (Laube et al. 2014a) and bud development under elevated air humidity (Laube et al. 2014b).

From the literature, it is known that under warmer spring temperatures, flowering is generally accelerated (Fu et al. 2012; Wang et al. 2020). In the study of Fu et al. (2012), potted saplings from beech, birch, and oak were treated with various temperature manipulations in climate chambers. It revealed that spring warming is more influential on budburst than winter warming and that spring warming (forcing) leads to an earlier budburst. A strong correlation between temperatures in March and the start of pollen season/in situ observed flowering phenology was also observed for birch (Bogawski et al. 2019; Newnham et al. 2013). Another study on birch (Miller-Rushing and Primack 2008) reported that the inflorescence length does not influence the start of flowering. Other studies have shown that the responses to changed climatic conditions are highly species-specific (Laube et al. 2014a; Malyshev 2020; Miller-Rushing and Primack 2008).

The objective of this study was to establish the twig method in climate chambers for the investigation of allergenic pollen. In order to observe the impact of harvesting on flowering and pollen characteristics, an outdoor comparison between cut and uncut inflorescences regarding their pollen production and pollen characteristics was conducted. We examined whether branch experiments in climate chambers can be used as a proxy for outdoor manipulations on pollen. In pollen research, the harvesting of twigs shortly before flowering is required, and then the pollen has to be emitted under controlled conditions in the climate chamber. Furthermore, it was evaluated under controlled conditions in the climate chamber whether the usage of different fertilizers as an additive in the irrigation causes favorable/unfavorable conditions for pollen production and has an impact on pollen characteristics as previous studies suggested for flowering and number of inflorescences (ALKahtani and Ahmed 2012; Maksoud 2000).

\section{Material and methods}

\section{Investigated species and tree selection}

We chose the widespread shrub species Corylus avellana (hazel) and tree species Alnus glutinosa (common alder) and Betula pendula (silver birch), which are characterized by a high allergenicity of their pollen and the availability of common allergens (cross-reactive Bet v1) (Biedermann et al. 2019; Niederberger et al. 1998; Weber 2003). These species are monoecious with typical long catkins containing only male flowers (Filbrandt-Czaja and Adamska 2018). Hazel and alder flower early in January to March, whereas birch flowers later in March to June (only in northern latitudes).

The sampling took place on the specimen in the $3 \mathrm{~km}$ surroundings of the campus of the Technical University of Munich at Freising/Weihenstephan (48.400292 N, $11.716874 \mathrm{E}$ ). Care was taken to ensure that the selected trees had a minimum distance of $15 \mathrm{~m}$ from buildings and varied in age, diameter, and height. From this selection, 3 hazel, 2 alder, and 2 birch tree specimen were chosen. Heights were measured with a relascope, diameters were measured with a tape measure, and ages were estimated. The selected hazels were approximately of the same age (20 years old), height $(8 \mathrm{~m})$, crown length $(6 \mathrm{~m})$, and diameter $(20 \mathrm{~cm})$ and had similar densities to male catkins. The two alder trees were likely of the same age ( 25 years old), height $(15 \mathrm{~m})$, crown length (13 $\mathrm{m}$ ), and diameter $(30 \mathrm{~cm})$ and had about the same number of male catkins. The two birch specimens were of different estimated age ( 30 and 50 years old), height ( 15 and $25 \mathrm{~m}$ ), crown length $(13$ and $23 \mathrm{~m})$, and diameter $(30$ and $40 \mathrm{~cm})$.

\section{Harvest and treatments of twigs}

The investigation period was from the 5th of November 2018 to the 18th of April 2019. Twigs of the respective species and specimens were harvested in weekly intervals before the actual flowering (Table 1). It was assured that the harvested twigs (length 40 to $50 \mathrm{~cm}$ ) had the required minimum number of five male inflorescences. The sampling height was $2-3 \mathrm{~m}$ above the ground level. After cutting, the twigs were disinfected with $90 \%$ ethanol and their basis was recut underwater to avoid disruption of water uptake. The twigs were then stored in glass bottles (capacity $100 \mathrm{ml}$ ) which were filled with tap water.

Previous experiments suggested that the usage of different fertilizers as an additive in irrigation may have influence on development of the inflorescences (AL-Kahtani and Ahmed 2012; Maksoud 2000). Therefore, hazel was treated 
Table 1 Overview on harvested twigs including the following: species, specimen number, flowering location (indoors or outdoors); cutting date; number of twigs analyzed in the laboratory (number of twigs exclusively analyzed for allergen content in square brackets []): indoors: climate chamber (CC) and window sill (WS) subdivided into treatments control (C), plant fertilizer (PF), tissue fertilizer (TF), and outdoors: into the treatments cut and uncut; Flowering date refers to the observation date where $\mathrm{BBCH} 60$ was recorded

\begin{tabular}{|c|c|c|c|c|c|}
\hline Species & Specimen & $\begin{array}{l}\text { In-/ } \\
\text { outdoors }\end{array}$ & Cutting date & Number of twigs analyzed in the laboratory & Flowering [BBCH 60] \\
\hline Hazel & 1 and 2 & Indoors & $12-06-2018$ & $\mathrm{CC}(5[2] \mathrm{C}, 4[1] \mathrm{PF}, 8[2] \mathrm{TF}), \mathrm{WS}(5[2] \mathrm{C}, 3[1] \mathrm{PF}, 4[2] \mathrm{TF})$ & $12-13-2018$ \\
\hline Hazel & 1 and 2 & Indoors & $12-12-2018$ & $\mathrm{CC}(4[2] \mathrm{C}, 3[1] \mathrm{PF}, 7$ [1] TF), WS (5 C, 4 [3] PF, $2 \mathrm{TF})$ & $12-18-2018$ \\
\hline Hazel & 3 & Outdoors & 02-13-2019 & $3[1]$ cut, 5 [1] uncut & 02-19-2019 \\
\hline Alder & 1 and 2 & Indoors & 01-21-2019 & CC (1 [1] C, 4 [1] TF), WS (3 [2] C, 2 [1] TF) & 01-31-2019 \\
\hline Alder & 1 and 2 & Outdoors & 02-13-2019 & 2 [1] cut, 3 [2] uncut & 03-06-2019 \\
\hline Alder & 1 and 2 & Outdoors & 02-25-2019 & 3 [2] cut, 2 [1] uncut & 03-06-2019 \\
\hline Alder & 1 and 2 & Outdoors & 02-28-2019 & $1[1]$ uncut & 03-06-2019 \\
\hline Birch & 1 and 2 & Indoors & 03-12-2019 & $\mathrm{CC}(6[2] \mathrm{C}, 4[2] \mathrm{TF}), \mathrm{WS}(4 \mathrm{C}, 3$ [1] TF) & 03-21-2019 \\
\hline Birch & 2 & Indoors & 03-29-2019 & $\mathrm{CC}(3[1] \mathrm{C}, 3[2] \mathrm{TF}), \mathrm{WS}(3 \mathrm{C}, 2 \mathrm{TF})$ & 04-04-2019 \\
\hline Birch & 2 & Indoors & 04-04-2019 & $\mathrm{CC}(5$ [1] C), WS (5 [1] C) & 04-04-2019 \\
\hline Birch & 2 & Outdoors & 03-22-2019 & $1[1]$ uncut & 04-04-2019 \\
\hline Birch & 2 & Outdoors & 03-23-2019 & $1[1]$ uncut & 04-04-2019 \\
\hline Birch & 2 & Outdoors & 03-29-2019 & 2 cut, 3 [1] uncut & 04-04-2019 \\
\hline Birch & 2 & Outdoors & 04-04-2019 & 4 [2] cut, 7 [3] uncut & 04-04-2019 \\
\hline Birch & 2 & Outdoors & 04-06-2019 & 4 [1] cut, 5 [1] uncut & 04-04-2019 \\
\hline Birch & 2 & Outdoors & 04-09-2019 & $6[1]$ uncut & 04-04-2019 \\
\hline
\end{tabular}

respectively with pure water, tissue fertilizer (B5 medium$100 \mathrm{ml} /$ liter), and plant fertilizer (nitrogen (N) 8\%, phosphorus $\left(\mathrm{P}_{2} \mathrm{O}_{5}\right) 8 \%$, potassium $\left(\mathrm{K}_{2} \mathrm{O}\right) 6 \%-1 \mathrm{ml} /$ liter $)$ (Table 1). Since the first sampling series on hazel twigs did not show any difference in the development of inflorescences between the fertilizers, twigs of alder and birch were treated with pure water and tissue fertilizer only. Additionally, to each substrate, Chrysal Clear was added as remedy against mold growth.

The twig samples were then stored in the climate chamber which was running under a day-night cycle of 15 and $9 \mathrm{~h}$, with $20{ }^{\circ} \mathrm{C}$ and $15{ }^{\circ} \mathrm{C}$ air temperature, respectively (Fig. 1). As backup in case of technical failures, a second set of samples was kept under room conditions on a window sill within the university building. Those conditions did not reflect any climate scenario; they were merely used to achieve flowering and pollen shedding.

\section{Comparison of cut and uncut twigs on donor trees}

For hazel, alder, and birch, on-tree comparisons between cut and uncut twigs under outdoor conditions were conducted. Single twigs with a minimum of five inflorescences were cut from the donor trees at different time intervals before natural flowering (Table 1) and directly put into plastic water containers (capacity $25 \mathrm{ml}$ ) which were afterwards attached vertically with wires to their original position. As a control, on the respective cutting dates, the same number of uncut twigs was selected on the donor trees in the surrounding of the cut twigs. Shortly before flowering, the cut and the selected uncut branches were covered with glassine bags for the in situ collection of pollen. After the pollen emission was completed, the twigs with their glassine bags were cut.

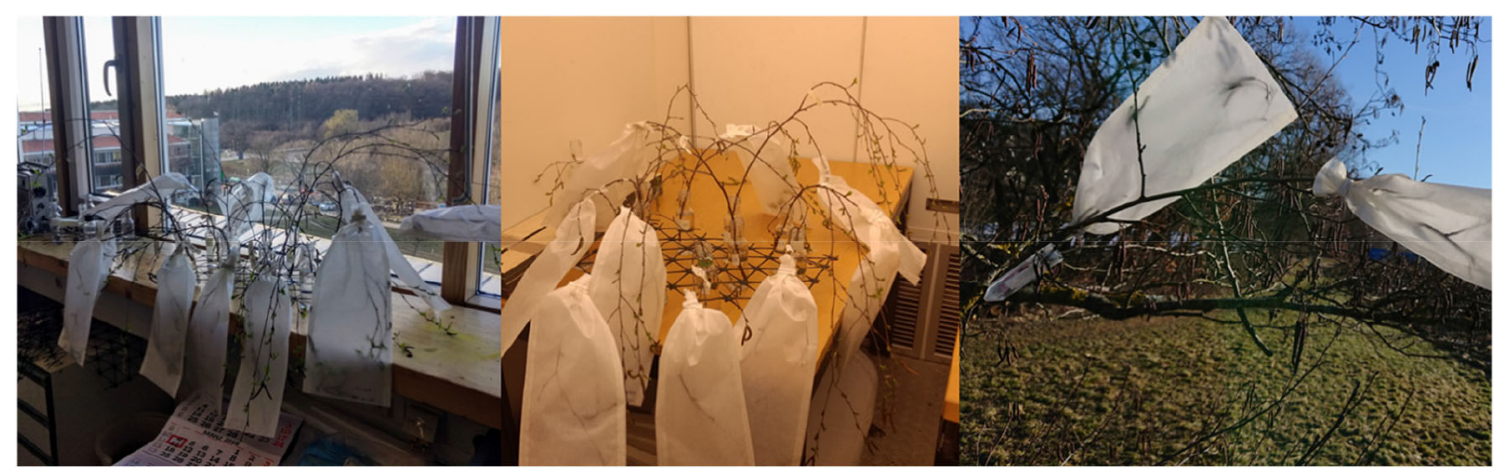

Fig. 1 Pollen collection in glassine bags from left to right: window sill, climate chamber, outdoor conditions 
Before separating the pollen from the anthers, the glassine bags had to be dried for approximately 1 week. Since the bags were only made of a material similar to paper, the outdoor in situ pollen collection was heavily impacted by precipitation (rain and snow) as well as by condensed water. The pollen already emitted into the bags got affected by humidity when the bags were soaked through. The inherent problem was that pollen partly burst into small pieces and after drying could not be separated from the paper anymore. To overcome this issue, we tried to cover the glassine bags additionally with plastic bags filled with a desiccant. Unfortunately, after a short time, condensation water had accumulated in the plastic bags causing similar issues as before. Still, part of the samples could be used for further laboratory analysis.

\section{Phenological observations and climatic parameters}

During the study period from the 5th of November, 2018, to the 18th of April, 2019, we recorded phenological stages once or twice a week according to the BBCH code (Meier 2001), with a particular focus on the period with sporadically first flowers open (BBCH 60). The $\mathrm{BBCH}$ was recorded indoors (climate chamber and window sill) and outdoors on the sampling trees. Temperature and air humidity were continuously measured in 30 min temporal resolution by Hobo Loggers (type U23 Pro v2), always at the height of the samples.

\section{Laboratory analysis}

After completion of flowering, the bags were inverted and gently shaken, resulting in accumulation of pollen at the bottom of the bags. After removal of the branches, the catkins/ anthers were manually separated from the pollen using tweezers. The remaining pure pollen was finally weighed. For each twig, the average pollen amount per catkin and the average catkin length were determined. The weighted pollen was stored at $-20^{\circ} \mathrm{C}$.

The subsequent laboratory analysis comprised the measurement of mean pollen weight per grain, protein content per grain, and allergen content. $5 \mathrm{mg}$ pollen was weighed in, and then $1 \mathrm{ml}$ buffer was added, and $20 \mu \mathrm{l}$ of this mixture was given onto a slide which was then inserted into a cell counter (Bio-Rad; type TC10) for automatic counting. The average pollen grain weight was derived from the initial weight (5 $\mathrm{mg}$ ) and the count from the instrument.

Before protein and allergen quantification, the protein had to be extracted from the pollen. For this purpose, $10 \mathrm{mg}$ pollen given in $1 \mathrm{ml}$ buffer was shaken continuously for $3 \mathrm{~h}$. The supernatant was stored at $-20{ }^{\circ} \mathrm{C}$. For protein quantification, we tested the BCA (Pierce BCA ${ }^{\mathrm{TM}}$ Protein Assay) and Bradford (Bio-Rad Protein Assay Dye Reagent Concentrate) methods in a pre-test with purification of the extract and gel electrophorese. The results of the Bradford test for protein content were in good agreement with other related studies (Ozler et al. 2009; Schäppi et al. 1997), while the results obtained with the BCA method showed much higher values. Therefore, protein quantification as protein content per pollen grain was performed using the Bradford test only. To determine allergen content, the Western blot technique was applied, which uses three different antibodies: human antibody (sera mixture of 29 patients who are allergic to Birch), monoclonal anti-human IgE antibody produced in mouse (Sigma-Aldrich), and rat antimouse IgG2b (-HRP conjugated, produced by The Monoclonal Antibody Core Facility at the Helmholtz Center ). After the application of all three antibodies, the allergens were detected in the last step under chemiluminescence (ECL ${ }^{\mathrm{TM}}$ select Western blotting detection reagent) (Fig. 2). Among the allergens visualized, the allergen Bet v1 showed the clearest signal as it is highly abundant. Bet $\mathrm{v} 1$ is cross-reactive in hazel, alder, and birch and can therefore be detected in all three species. For the calculation of Bet v1 allergen content, the signal intensity of chemiluminescence was extracted using the Fiji package from ImageJ (Rueden et al. 2017; Schindelin et al. 2012) and the protein content was determined via Ponceau $S$ staining during Western blotting. The allergen content was then calculated by dividing signal intensity and protein content, thus it is a relative value without unit. All laboratory analyses were conducted in cooperation with the Helmholtz Center.

\section{Statistics}

The statistical analysis was conducted in RStudio (version 3.5.1/2018-07-02). The per treatment distributions of the parameters average catkin length $(\mathrm{cm})$, average pollen weight per catkin (mg), pollen weight per grain (ng), protein content per grain (ng), and allergen content (unitless) were tested by the Shapiro-Wilk test for normality. Since the parameters were not normally distributed ( $\mathrm{p}$-value of Shapiro-Wilk test $<0.05$ ), nonparametric tests were further used: Student's t-test for comparisons between two groups, the univariate ANOVA (Kruskal-

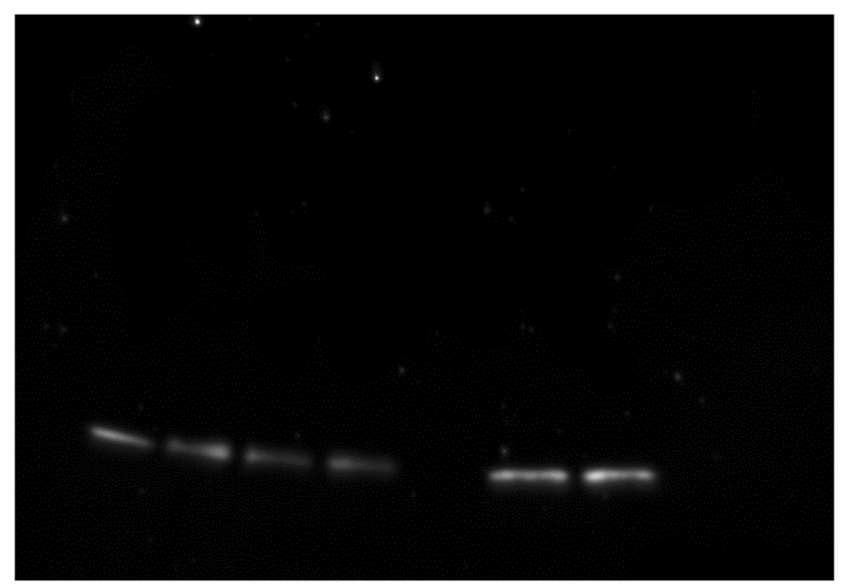

Fig. 2 Western blot-chemiluminescence measurement for six alder samples, measurement time $100 \mathrm{~s}$ 
Wallis test) for comparisons with more than two groups, and subsequently using pair-wise Wilcoxon tests for individual group comparison. $\mathrm{p}$-values less than 0.05 were considered statistically significant. Due to the limited number of samples per treatment which could be analyzed for the pollen weight per grain (ng) and allergen content, no statistical test could be performed and thus, only differences are shown in the results.

\section{Results}

During the investigation period, temperature and relative air humidity outdoors were on average $3.7^{\circ} \mathrm{C}$ and $81.9 \%$ respectively, whereby the minimum daily air temperature of $-6.2{ }^{\circ} \mathrm{C}$ was reached on the 20th of January 2019 and the maximum air humidity of $99.9 \%$ on the 11 th of January 2019 , and the maximum of $23.6{ }^{\circ} \mathrm{C}$ and the minimum relative air humidity of $26.7 \%$ both on the 18th of April 2019. Indoors, in the climate chamber, $16.8{ }^{\circ} \mathrm{C}$ and $73.3 \%$ and on the window sill $18.6^{\circ} \mathrm{C}$ and $35.3 \%$ (air temperature and humidity respectively) were recorded on average (Fig. 3).

Hazel was harvested for the indoor experiments twice on the 6th and 12th of December 2018, for the outdoor cut/uncut investigation twigs were cut/selected on the 13th of February 2019. First flowering (BBCH 60) both in the climate chamber/ on the window sill was observed for the twigs cut on the 6th of December 2018 on the 13th of December 2018 and for the twigs cut on the 12th of December on the 18th of December, under outdoor conditions for both the cut and selected twigs on the 19th of February 2019 (Table 1).
Between the two fertilizers and the control, significant differences were found in protein content $(p<0.057)$, and no significant differences in length per catkin $(\mathrm{p}=0.28)$ and in pollen weight per catkin ( $\mathrm{p}=0.11$ ) (Fig. 4). There were no significant differences in any of these parameters between the two harvesting dates (the 6th and 12th of December 2018). In comparison to the outdoor conditions, the catkin length and the weight per pollen grain were significantly smaller in the climate chamber/window sill $(\mathrm{p}=0.031$ and $\mathrm{p}=0.0013)$. Under outdoor conditions, the cut treatment showed a higher average pollen grain weight $(14.4 \mathrm{ng})$ than the uncut treatment $(6.5$ ng). For the allergen content, an opposite behavior was observed. The uncut treatment had higher allergen content (2.3) than the cut treatment (1.7).

Alder was harvested on the 21st of January 2019 for indoor investigation; outdoor twigs were cut/selected on the 13th, 25th, and 28th of February 2019. Flowering in the climate chamber/window sill was recorded on the 31th of January 2019, under outdoor conditions on the 6th of March 2019. Between the treatments tissue fertilizer and the control, no significant differences were found (Fig. 5). There were significant differences in the protein content between climate chamber/window sill and outdoor conditions $(\mathrm{p}=0.046)$. For the catkin length and the pollen weight in the climate chamber/window sill, no results were available. Under outdoor conditions, the average pollen grain weight (ng) was higher for the uncut $(12.7 \mathrm{ng})$ than the cut treatment $(9.2 \mathrm{ng})$.

Birch was harvested on the 12th and 29th of March and the 9th of April 2019; outdoor twigs were cut/selected on the 22nd, 23rd, and 29th of March and on the 4th, 6th,
Fig. 3 Temperature $\left({ }^{\circ} \mathrm{C}\right)$ and relative humidity $(\%)$ indoors at the window sill, in the climate chamber, and outdoors during the investigation period 5 th of November 2018 to 18th of April 2019

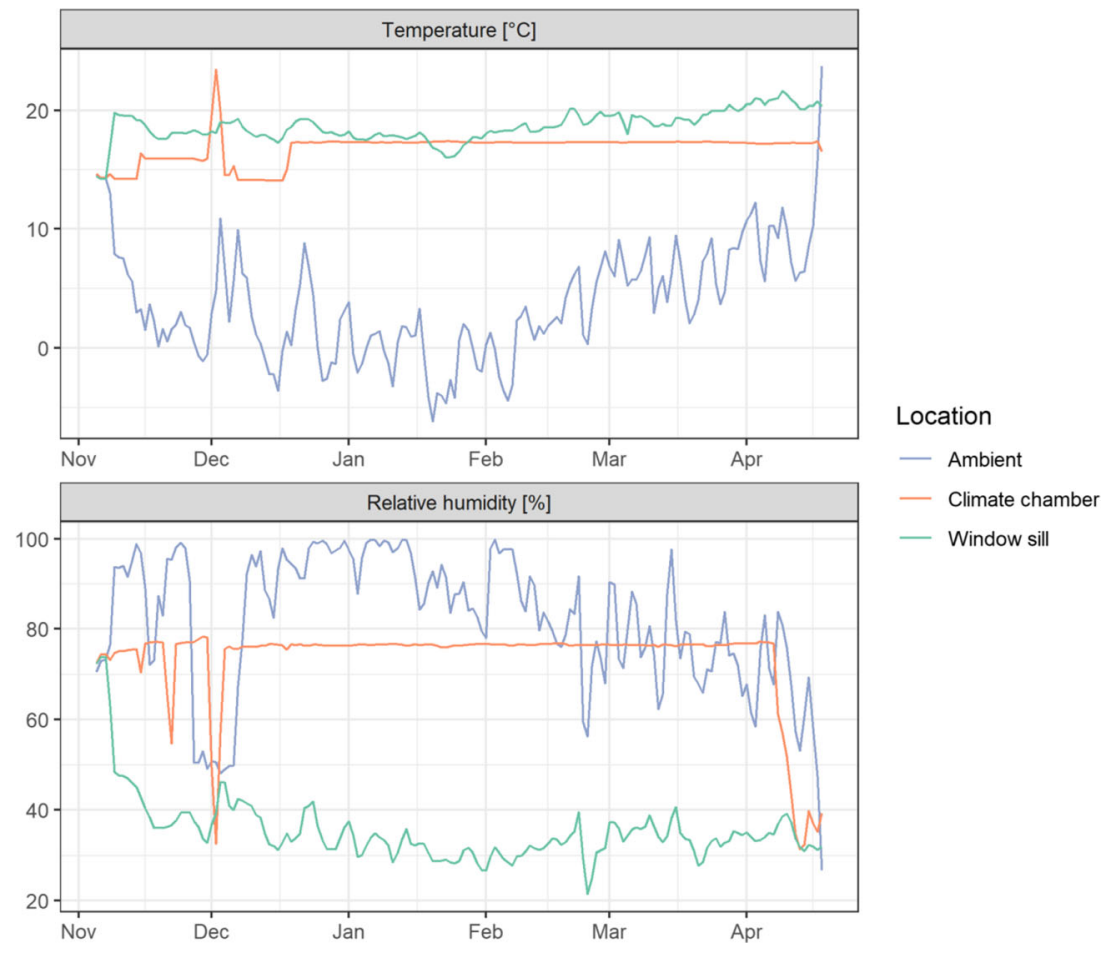



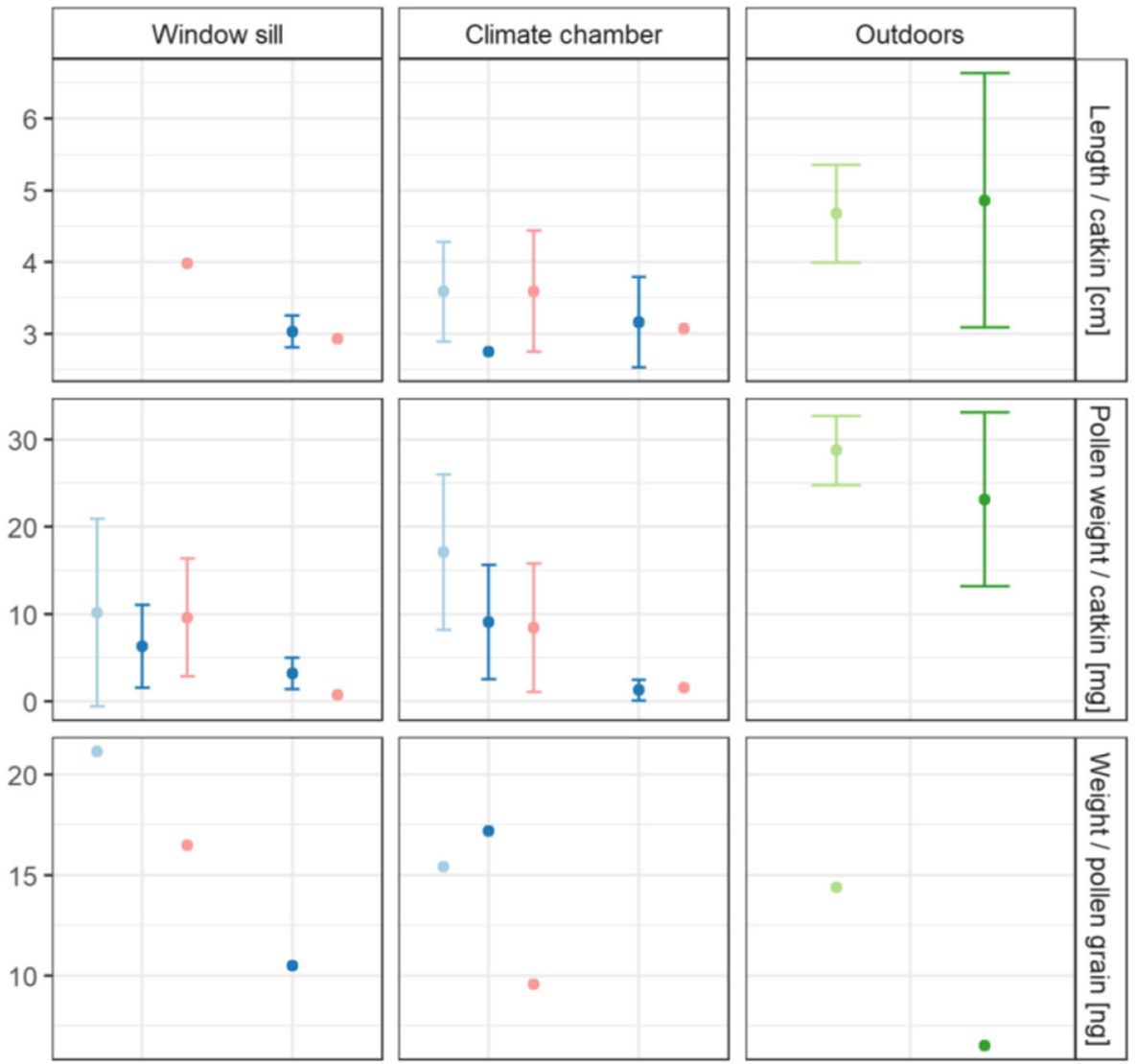

\section{Treatment}

- Tissue fertilizer

$\rightarrow$ Plant fertilizer

$\rightarrow$ Control

$\rightarrow$ Cut

$\rightarrow$ Uncut
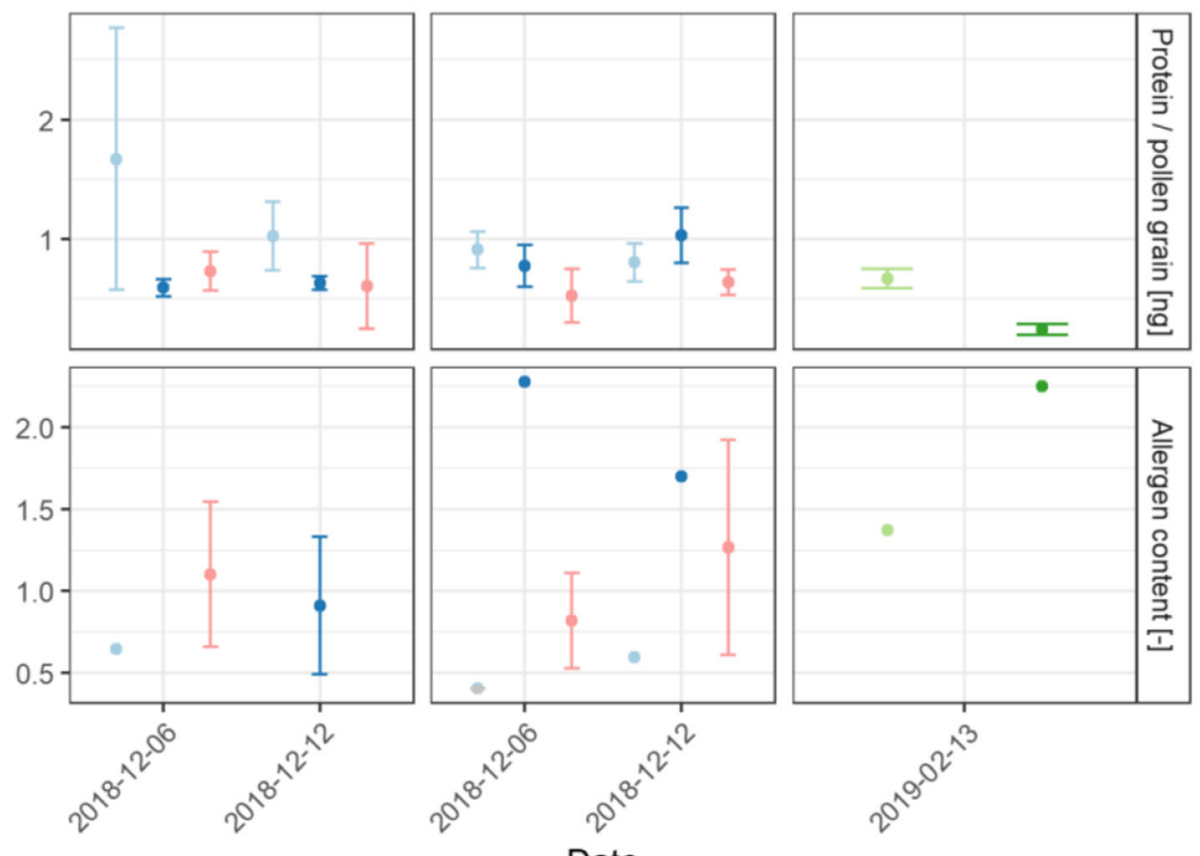

Date

Fig. 4 Results of the laboratory analysis for hazel: length per catkin $(\mathrm{cm})$, average pollen grain weight (ng), protein content per pollen grain (ng), and allergen content (unitless) for the respective indoor flowering locations

window sill and climate chamber, as well as outdoors under the treatments tissue fertilizer, plant fertilizer, control, cut and uncut for different harvesting dates; bars represent standard deviation according to the sample size

and 9th of April 2019. Flowering in the climate chamber/ window sill from the twigs cut on the 12th of March was observed on the 21th of March 2019 and for the two later

cuttings on the 29th of March and 4th of April flowering could be monitored on the 4th of April. Outdoors flowering was observed on the 4th of April 2019. There 

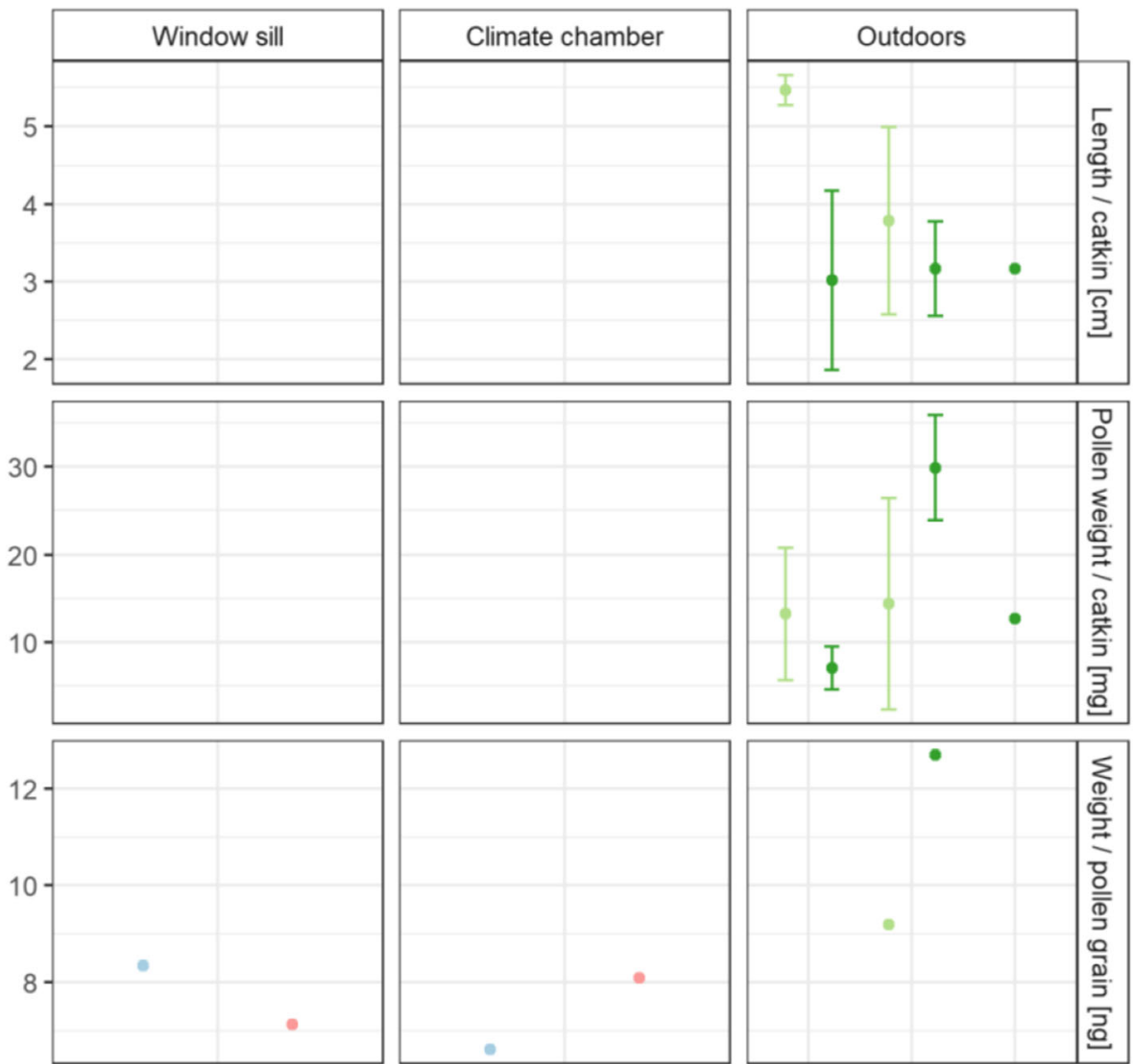

Treatment

- Tissue fertilizer

$\rightarrow$ Control

$\rightarrow$ Cut

$\rightarrow$ Uncut
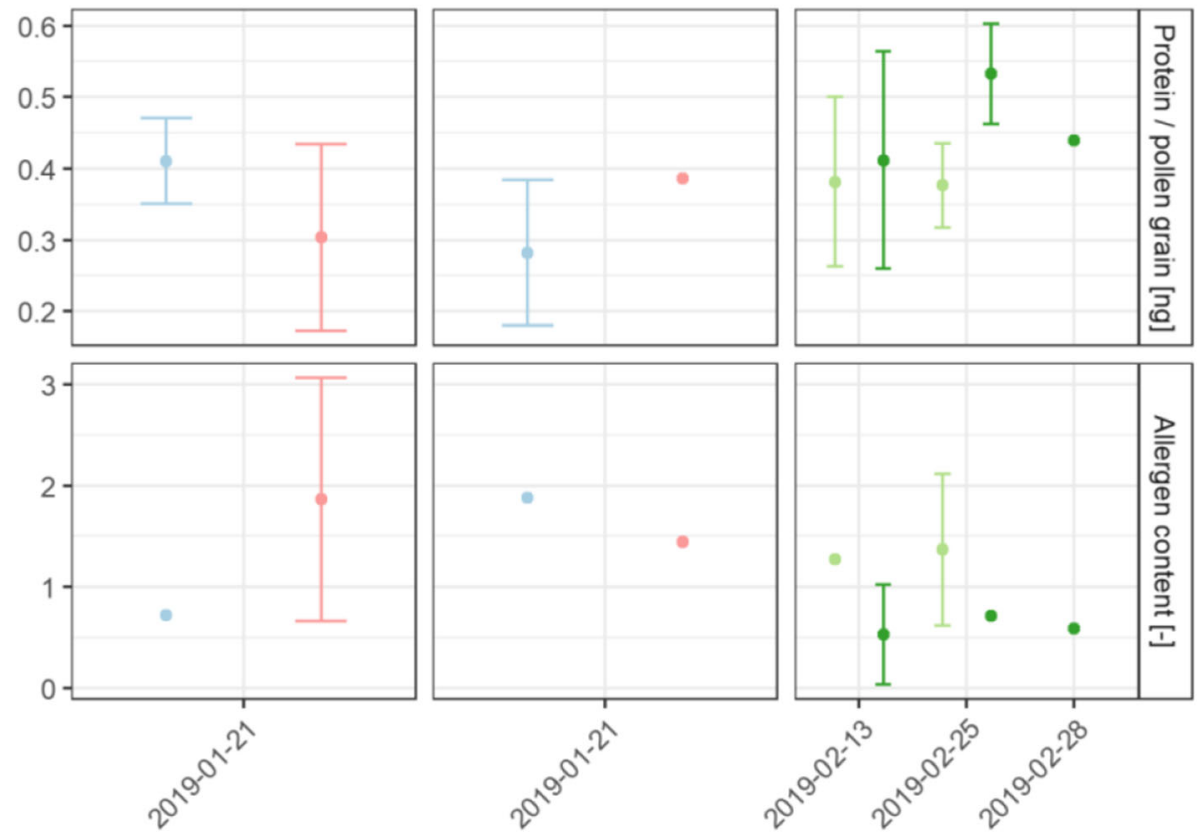

Date

Fig. 5 Results of the laboratory analysis for alder: length per catkin $(\mathrm{cm})$, average pollen grain weight (ng), protein content per pollen grain (ng), and allergen content (unitless) for the respective flowering locations window sill and climate chamber, and outdoors under the treatments tissue

fertilizer, plant fertilizer, control, cut and uncut for different harvesting dates; bars represent standard deviation according to the sample size, missing data for length per catkin $(\mathrm{cm})$ and protein content per pollen grain (ng) for the cutting date 21th of January 2019

were no significant differences between the treatments tissue fertilizer and control in catkin length, pollen weight

per catkin, and protein content per grain (Fig. 6). Under controlled conditions in the climate chamber/window sill, 

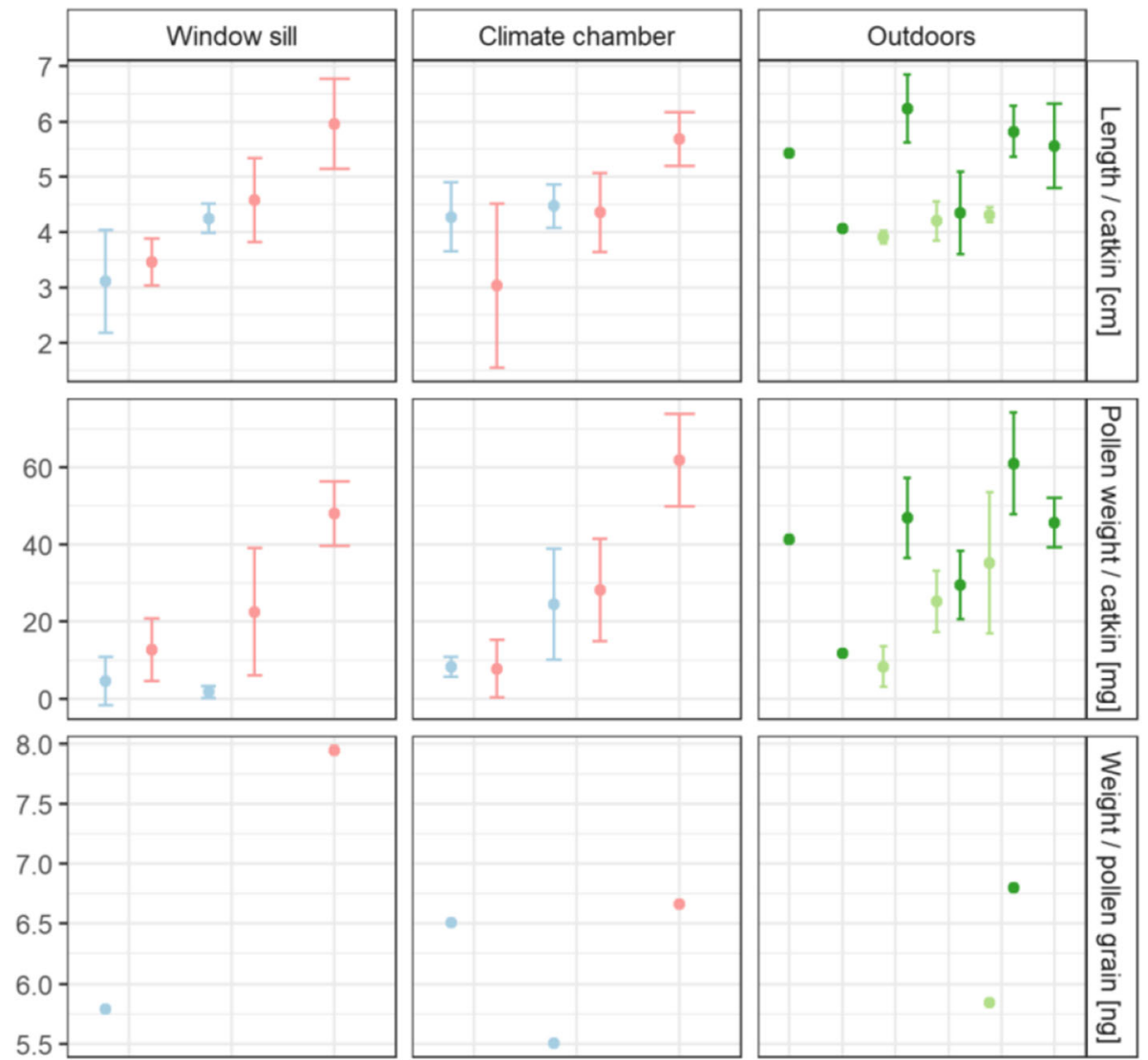

Treatment

- Tissue fertilizer

$\rightarrow$ Control

$\rightarrow$ Cut

$\rightarrow$ Uncut
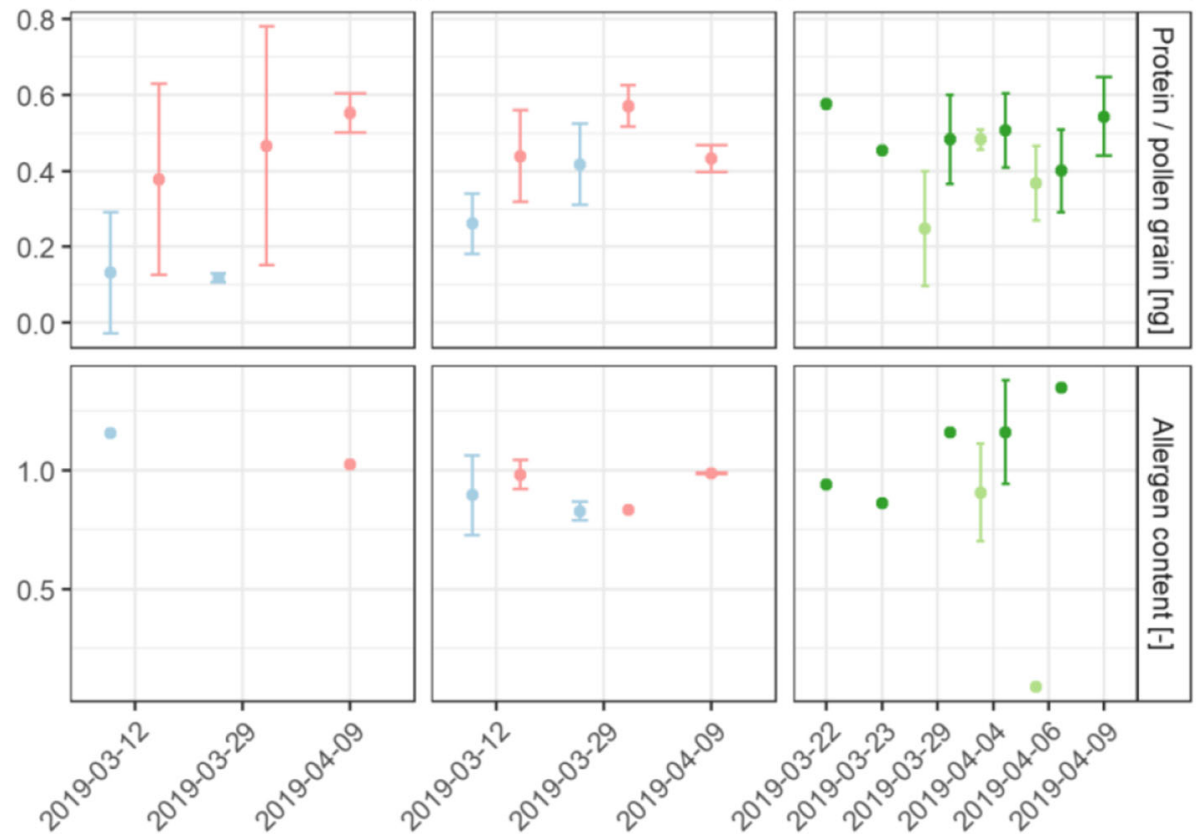

Date

Fig. 6 Results of the laboratory analysis for birch: length per catkin $(\mathrm{cm})$, average pollen grain weight (ng), protein content per pollen grain (ng), and allergen content (unitless) for the respective flowering locations wintreatments tissue fertilizer, plant fertilizer, control, cut and uncut for different harvesting dates; bars represent standard deviation according to the sample size

dow sill and climate chamber, and outdoor conditions under the

later, harvesting revealed higher values for the catkin length, the pollen weight per catkin, and the protein content. The results were significant for the parameters catkin length $(\mathrm{p}=0.0054)$, pollen weight per catkin 
$(p=0.023)$ but not for the protein content $(p=0.27)$. For the comparison between outdoor and the climate chamber/ window sill, significant differences were found for the catkin length $(\mathrm{p}=0.031)$ and pollen weight per catkin $(\mathrm{p}=0.0064)$ but not for the protein content $(\mathrm{p}=0.09)$. The average pollen grain weight was in the uncut treatment higher $(6.8 \mathrm{ng})$ than in the cut treatment $(5.9 \mathrm{ng})$.

\section{Discussion}

The main objective of this study was to establish the twig method in climate chambers for the investigation of flowering phenology and pollen characteristics of allergenic shrub/tree species. In order to evaluate whether the cutting of twigs influenced flowering, pollen emission, and pollen characteristics, a comparison of cut and uncut twigs outdoors on donor trees was conducted. The studied tree species hazel, alder, and birch showed in most cases (except birch on the 29th of March 2019) only marginal differences in the studied parameters (except average pollen grain weight and allergen content) for the outdoor comparison between cut and uncut branches. For allergen content and pollen weight per pollen grain, a higher sample number would be required for a solid assessment. Flowering occurred on the same day, the pollen amount emitted per catkin was similar and differences in the pollen characteristics were minor and not significant. Variations in the results for different twig selecting dates (uncut treatment having the same harvesting date) can be explained by a varying location of the selected twigs on the respective donor tree. Based on the results of the cut and uncut comparison on the donor trees, the usage of cut twigs can be recommended as appropriate for flowering and pollen investigations.

Furthermore, it was studied whether the usage of different fertilizers as an additive in irrigation has an influence on the vitality of the inflorescences and other observed parameters. Dormant twigs cut before natural flowering from hazel, alder, and birch were kept indoors under constant conditions in climate chamber or room condition (window sill) until full flowering and pollen emission. The respectively added plant and tissue fertilizer in contrast to other studies (AL-Kahtani and Ahmed 2012; Maksoud 2000) neither affected plant vitality nor the observed parameters. The weekly exchange of water seemed to be sufficient for proper inflorescence development as potentially occurring mold (Criado et al. 2005) could in the meantime be prevented by the addition of a remedy against fungal growth.

In order to study the possibility of using climate chamber experiments as proxy for outdoor manipulations, twigs were harvested in different intervals (see Table 1) before natural outdoor flowering and were kept in the climate chamber/ room conditions for flowering. In comparison to the outdoor conditions (average temperature $3.7^{\circ} \mathrm{C}$ ), a much earlier flowering was observed in the climate chamber (average temperature $16.8^{\circ} \mathrm{C}$ ) for hazel (-69 days), alder ( -35 days), and birch ( -15 days), ordered by their harvesting dates beginning of December, end of January, and beginning of March. Wang et al. (2020) observed similar trends in a climate chamber experiment on branches of six Asian woody species, where a $3{ }^{\circ} \mathrm{C}$ increase in spring temperature resulted in flowering advanced by 2.3 to 36.1 days, depending on the species. In the present study, an impact of the flowering time could be observed on the pollen amount produced, and on pollen characteristics for all investigated species. In the climate chamber, later branch harvesting and thus later flowering resulted in higher pollen production per catkin, catkin length, and protein content. This could be seen in the respective results from the climate chamber/window sill as compared to the outdoor conditions. For birch, the same dependency could be seen for the different harvesting dates between the 12th of March and the 9th of April. A study on birch from (Buters et al. 2010) showed a similar dependency for the allergen content, it strongly increased in the days before flowering. Related studies on birch have shown that climate warming can affect leaf size and the number of shoots developed (Hofgaard et al. 2010), as well as leaf phytochemistry (Jamieson et al. 2015).

Since the pollen weight per grain was not investigated for each harvesting date separately (due to lack of pollen amount), further experiments would be needed. The generally considerably lower relative humidity on the window sill (room temperature) in comparison to the climate chamber seemed not to affect the flowering timing nor pollen characteristics. It cannot be ruled out that there are still drivers that have not been accounted for but still influence flowering in the climate chamber (Wolkovich et al. 2012).

The taken twig samples from different harvesting dates were able to flower in the climate chamber/window sill. Flowering in the climate chamber/window sill occurred 510 days after harvesting of the twigs. The respective five catkins per twig sample produced a sufficient amount of pollen $(>10 \mathrm{mg}$ ) for further analysis in the laboratory. These results confirm that the twig methods in climate chambers can be a proxy for outdoor manipulations and can therefore be used for various experimental setups in pollen research (different climatic scenarios for temperature, air humidity, ozone, $\mathrm{CO}_{2}$ ) (Primack et al. 2015; Vitasse and Basler 2014).

A recent study by Ettinger et al. (2020) pointed out the dominant influence of winter temperatures on spring phenology and how manipulation experiments can contribute to its further exploration. Branch experiments can simulate variation in chilling length using different harvest dates prior to actual flowering or higher temperatures in the climate chamber/window sill can be used to study the effect of accelerated warming (forcing) (see e.g. Menzel et al. 2020a, b). 


\section{Conclusion}

The twig method in climate chambers has been already well established for observations on phenology, budburst, and leaf unfolding. The presented study could illustrate that the twig method in climate chambers is also well applicable for investigations on flowering and pollen characteristics. In situ comparisons on outdoor shrubs/trees revealed no significant difference between male catkins from cut and uncut twigs in their time of flowering and pollen characteristics. The addition of different fertilizers during the irrigation of the cut twigs did not show a significant effect on the vitality of the inflorescences nor the pollen characteristics. Twigs from hazel, birch, and alder were cut in different intervals before natural flowering and then kept under controlled conditions in the climate chamber/window sill for flowering. It could be seen that accelerating warming influences flowering and the pollen characteristics catkin length, pollen emission per catkin, and protein content. The twig samples from all cutting dates were able to produce an appropriate amount of pollen for the subsequent laboratory analysis. This shows that the twig method in climate chambers can be used as a proxy for outdoor manipulations in pollen research.

Acknowledgements We would like to thank Benjamin Meyer (TUM School of Life Sciences) for taking part in the fieldwork, Florian Schwarzfischer (TUM School of Life Sciences) and Dr. Ulrike Frank (Helmholtz Center München) for supporting the lab work, and Dr. Ye Yuan (TUM School of Life Sciences) for helping with the data visualization in $\mathrm{R}$.

Author contribution Conceived and designed the study: H.S.J., F.Z., A.M.; carried out the experiment: H.S.J.; analyzed the data: H.S.J.; writing — original draft preparation: H.S.J.; writing — review and editing: H.S.J., F.Z., A.M

Funding Open Access funding enabled and organized by Projekt DEAL. This study was conducted in the framework KlimaPOLLEN as part of the joint project "Climate Change and Health" and funded by the Bavarian State Ministry of the Environment and Consumer Protection and the Bavarian State Ministry of Health and Care.

\section{Declarations}

Conflict of interest The authors declare no competing interests.

Open Access This article is licensed under a Creative Commons Attribution 4.0 International License, which permits use, sharing, adaptation, distribution and reproduction in any medium or format, as long as you give appropriate credit to the original author(s) and the source, provide a link to the Creative Commons licence, and indicate if changes were made. The images or other third party material in this article are included in the article's Creative Commons licence, unless indicated otherwise in a credit line to the material. If material is not included in the article's Creative Commons licence and your intended use is not permitted by statutory regulation or exceeds the permitted use, you will need to obtain permission directly from the copyright holder. To view a copy of this licence, visit http://creativecommons.org/licenses/by/4.0/.

\section{References}

AL-Kahtani SH, Ahmed MA (2012) Effect of different mixtures of organic fertilizers on vegetative growth, flowering, fruiting and leaf mineral content of Picual olive trees. Agric \& Environ Sci 12:11051112

Basler D, Körner C (2012) Photoperiod sensitivity of bud burst in 14 temperate forest tree species. Agric For Meteorol 165:73-81. https://doi.org/10.1016/j.agrformet.2012.06.001

Beggs PJ (2004) Impacts of climate change on aeroallergens: past and future. Clin Exp Allergy 34:1507-1513. https://doi.org/10.1111/j. 1365-2222.2004.02061.x

Biedermann T, Winther L, Till SJ, Panzner P, Knulst A, Valovirta E (2019) Birch pollen allergy in Europe. Allergy:1237-1248. https:// doi.org/10.1111/all.13758

Bogawski P, Grewling Ł, Jackowiak B (2019) Predicting the onset of Betula pendula flowering in Poznań (Poland) using remote sensing thermal data. Sci Total Environ 658:1485-1499. https://doi.org/10. 1016/j.scitotenv.2018.12.295

Brennan GL, Potter C, Vere N, Griffith GW, Skjøth CA, Osborne NJ, Wheeler BW, McInnes RN, Clewlow Y, Barber A, Hanlon HM, Hegarty M, Jones L, Kurganskiy A, Rowney FM, Armitage C, Adams-Groom B, Ford CR, Petch GM, Creer S (2019) Temperate airborne grass pollen defined by spatio-temporal shifts in community composition. Nat Ecol Evol 3:750-754. https://doi.org/10.1038/ s41559-019-0849-7

Bufe A, Spangfort MD, Kahlert H, Schlaak M, Becker WM (1996) The major birch pollen allergen, Bet $\mathrm{v} 1$, shows ribonuclease activity. Planta 199:413-415. https://doi.org/10.1007/BF00195733

Buters JTM, Weichenmeier I, Ochs S, Pusch G, Kreyling W, Boere AJF, Schober W, Behrendt H (2010) The allergen Bet v 1 in fractions of ambient air deviates from birch pollen counts. Allergy 65:850-858. https://doi.org/10.1111/j.1398-9995.2009.02286.x

Criado MV, Fernández Pinto VE, Badessari A, Cabral D (2005) Conditions that regulate the growth of moulds inoculated into bottled mineral water. Int J Food Microbiol 99:343-349. https://doi.org/ 10.1016/j.ijfoodmicro.2004.10.036

D'Amato G, Cecchi L, Bonini S, Nunes C, Annesi-Maesano I, Behrendt H, Liccardi G, Popov T, van Cauwenberge P (2007) Allergenic pollen and pollen allergy in Europe. Allergy 62:976-990. https:// doi.org/10.1111/j.1398-9995.2007.01393.x

Dantec CF, Vitasse Y, Bonhomme M, Louvet J, Kremer A, Delzon S (2014) Chilling and heat requirements for leaf unfolding in European beech and sessile oak populations at the southern limit of their distribution range. Int J Biometeorol 58:1853-1864. https://doi.org/10.1007/s00484-014-0787-7

Ettinger AK, Chamberlain CJ, Morales-Castilla I, Buonaiuto DM, Flynn DFB, Savas T, Samaha JA, Wolkovich EM (2020) Winter temperatures predominate in spring phenological responses to warming. Nat Clim Chang 10:1137-1142. https://doi.org/10.1038/s41558020-00917-3

Filbrandt-Czaja A, Adamska E (2018) The analysis of the Corylus, Alnus and Betula pollen seasons in Torun in 2014 and 2016. EQ 29:1. https://doi.org/10.12775/EQ.2018.018

Frei T, Gassner E (2008) Climate change and its impact on birch pollen quantities and the start of the pollen season an example from Switzerland for the period 1969-2006. Int J Biometeorol 52:667674. https://doi.org/10.1007/s00484-008-0159-2

Fu YH, Campioli M, Deckmyn G, Janssens IA (2012) The impact of winter and spring temperatures on temperate tree budburst dates: results from an experimental climate manipulation. PLoS One 7: e47324. https://doi.org/10.1371/journal.pone.0047324

Grewling Ł, Bogawski P, Kostecki Ł, Nowak M, Szymańska A, Frątczak A (2020) Atmospheric exposure to the major Artemisia pollen allergen (Art v 1): Seasonality, impact of weather, and clinical 
implications. Sci Total Environ 713:136611. https://doi.org/10. 1016/j.scitotenv.2020.136611

Hanna WW (1990) Long-term storage of Pennisetum glaucum (L.) R. Br. pollen. Theor Appl Genet 79(5):605-608

Hofgaard A, Løkken JO, Dalen L, Hytteborn H (2010) Comparing warming and grazing effects on birch growth in an alpine environment - a 10-year experiment. Plant Ecology \& Diversity 3:19-27. https://doi.org/10.1080/17550871003717016

Jamieson MA, Schwartzberg EG, Raffa KF, Reich PB, Lindroth RL (2015) Experimental climate warming alters aspen and birch phytochemistry and performance traits for an outbreak insect herbivore. Glob Chang Biol 21:2698-2710. https://doi.org/10.1111/gcb.12842

Jung S, Estrella N, Pfaffl MW, Hartmann S, Handelshauser E, Menzel A (2018) Grass pollen production and group V allergen content of agriculturally relevant species and cultivars. PLoS One 13: e0193958. https://doi.org/10.1371/journal.pone.0193958

Laube J, Sparks TH, Estrella N, Höfler J, Ankerst DP, Menzel A (2014a) Chilling outweighs photoperiod in preventing precocious spring development. Glob Chang Biol 20:170-182. https://doi.org/10.1111/ gcb. 12360

Laube J, Sparks TH, Estrella N, Menzel A (2014b) Does humidity trigger tree phenology? Proposal for an air humidity based framework for bud development in spring. New Phytol 202:350-355. https://doi. org/10.1111/nph.12680

Maksoud MA (2000) Response of growth and flowering of "Manzanillo" olive trees to different sorts of nutrients. Egypt J Hortic 27:513-523

Malyshev AV (2020) Warming events advance or delay spring phenology by affecting bud dormancy depth in trees. Front Plant Sci 11:856. https://doi.org/10.3389/fpls.2020.00856

Marselle, Stadler J, Korn H, Irvine KN, Bonn A (2019) Biodiversity and health in the face of climate change. Springer International Publishing, Cham

Meier U (2001) Entwicklungsstadien mono- und dikotyler Pflanzen. Die erweiterte BBCH Monographie 2

Menzel A, Sparks TH, Estrella N, Koch E, Aasa A, Ahas R, Alm-Kübler K, Bissolli P, Braslavka O, Briede A, Chmielewski FM, Crepinsek Z, Curnel Y, Dahl Å, Defila C, Donnelly A, Fillella Y, Jatczak K, Mage F, Mestre A, Penuelas J, Pirinen P, Remisova V, Scheifinger H, Striz M, Susnik A, van Vliet AJH, Wielgolaski FE, Zach S, Zust A (2006) European phenological response to climate change matches the warming pattern. Glob Chang Biol 12:1969-1976. https://doi.org/10.1111/j.1365-2486.2006.01193.x

Menzel A, Yuan Y, Hamann A, Ohl U, Matiu M (2020a) Chilling and forcing from cut twigs - how to simplify phenological experiments for citizen science. Front Plant Sci 11:281. https://doi.org/10.3389/ fpls.2020.561413

Menzel A, Yuan Y, Matiu M, Sparks T, Scheifinger H, Gehrig R, Estrella $\mathrm{N}$ (2020b) Climate change fingerprints in recent European plant phenology. Glob Chang Biol 26:2599-2612. https://doi.org/10. $1111 / \mathrm{gcb} .15000$

Menzel A, Ghasemifard H, Yuan Y, Estrella N (2021) A first pre-season pollen transport climatology to bavaria. Germany FrontAllergy 2. https://doi.org/10.3389/falgy.2021.627863

Miller-Rushing AJ, Primack RB (2008) Effects of winter temperatures on two birch (Betula) species. Tree Physiol 28:659-664. https://doi. org/10.1093/treephys/28.4.659

Newnham RM, Sparks TH, Skjøth CA, Head K, Adams-Groom B, Smith M (2013) Pollen season and climate: is the timing of birch pollen release in the UK approaching its limit? Int J Biometeorol 57:391400. https://doi.org/10.1007/s00484-012-0563-5

Niederberger V, Pauli G, Grönlund H, Fröschl R, Rumpold H, Kraft D, Valenta R, Spitzauer S (1998) Recombinant birch pollen allergens (rBet v 1 and rBet v 2) contain most of the IgE epitopes present in birch, alder, hornbeam, hazel, and oak pollen: a quantitative IgE inhibition study with sera from different populations. J Allergy Clin Immunol 102:579-591. https://doi.org/10.1016/s00916749(98)70273-8

Ozler H, Pehlivan S, Bayrak F (2009) Analysis of free amino acid and total protein content in pollen of some allergenic taxa. Asian J Plant Sci 8:308-312. https://doi.org/10.3923/ajps.2009.308.312

Primack RB, Laube J, Gallinat AS, Menzel A (2015) From observations to experiments in phenology research: investigating climate change impacts on trees and shrubs using dormant twigs. Ann Bot 116:889 897. https://doi.org/10.1093/aob/mcv032

Rosenzweig C, Karoly D, Vicarelli M, Neofotis P, Wu Q, Casassa G, Menzel A, Root TL, Estrella N, Seguin B, Tryjanowski P, Liu C, Rawlins S, Imeson A (2008) Attributing physical and biological impacts to anthropogenic climate change. Nature 453:353-357. https://doi.org/10.1038/nature06937

Rueden CT, Schindelin J, Hiner MC, DeZonia BE, Walter AE, Arena ET, Eliceiri KW (2017) ImageJ2: ImageJ for the next generation of scientific image data. BMC Bioinformatics 18:529. https://doi.org/ 10.1186/s12859-017-1934-Z

Schäppi GF, Suphioglu C, Taylor P, Knox R (1997) Concentrations of the major birch tree allergen Bet $\mathrm{v} 1$ in pollen and respirable fine particles in the atmosphere. J Allergy Clin Immunol 100:656-661. https://doi.org/10.1016/S0091-6749(97)70170-2

Schäppi GF, Taylor PE, Pain MC, Cameron PA, Dent AW, Staff IA, Suphioglu C (1999) Concentrations of major grass group 5 allergens in pollen grains and atmospheric particles: implications for hay fever and allergic asthma sufferers sensitized to grass pollen allergens. Clin Exp Allergy 29:633-641. https://doi.org/10.1046/j.13652222.1999.00567.x

Schindelin J, Arganda-Carreras I, Frise E, Kaynig V, Longair M, Pietzsch T, Preibisch S, Rueden C, Saalfeld S, Schmid B, Tinevez JY, White DJ, Hartenstein V, Eliceiri K, Tomancak P, Cardona A (2012) Fiji: an open-source platform for biological-image analysis. Nat Methods 9:676-682. https://doi.org/10.1038/nmeth.2019

Sofiev M, Bergmann K-C (2013) Allergenic pollen. Springer Netherlands, Dordrecht

Vitasse Y, Basler D (2014) Is the use of cuttings a good proxy to explore phenological responses of temperate forests in warming and photoperiod experiments? Tree Physiol 34:174-183. https://doi.org/10. 1093/treephys/tpt116

Wang H, Ge Q, Dai J (2020) The interactive effects of chilling, photoperiod, and forcing temperature on flowering phenology of temperate woody plants. Front Plant Sci 11:443. https://doi.org/10.3389/fpls. 2020.00443

Weber RW (2003) Patterns of pollen cross-allergenicity. J Allergy Clin Immunol 112:229-239; quiz 240. https://doi.org/10.1067/mai.2003. 1683

Wolkovich EM, Cook BI, Allen JM, Crimmins TM, Betancourt JL, Travers SE, Pau S, Regetz J, Davies TJ, Kraft NJB, Ault TR, Bolmgren K, Mazer SJ, McCabe GJ, McGill BJ, Parmesan C, Salamin N, Schwartz MD, Cleland EE (2012) Warming experiments underpredict plant phenological responses to climate change. Nature 485:494-497. https://doi.org/10.1038/nature11014 